\title{
THE SOCIO-ECONOMIC IMPACT OF AFRICA'S OLDEST MARINE PARK
}

Authors:

Susan Oberholzer

Melville Saayman

Andrea Saayman ${ }^{2}$

Elmarie Slabbert ${ }^{1}$

\section{Affiliations:}

${ }^{1}$ Institute for Tourism and Leisure Studies,

North-West University,

Potchefstroom campus,

South Africa

${ }^{2}$ School of Economics,

North-West University,

Potchefstroom campus,

South Africa

Correspondence to:

Melville Saayman

email:

melville.saayman@nwu. ac.za

\section{Postal address:}

Private Bag X6001,

Potchefstroom 2521,

South Africa

Keywords:

community; marine tourism; national parks; partial multiplier modelling; regional economy; socio-economic impact; tourism

\section{Dates:}

Received: 06 July 2009

Accepted: 29 June 2010

Published: 21 Sept. 2010

How to cite this article: Oberholzer, S., Saayman, M., Saayman, A. \& Slabbert, E., 2010, 'The socio-economic impact of Africa's oldest marine park', Koedoe 52(1), Art. \#879, 9 pages. DOI: 10.4102/koedoe.v52i1.879

This article is available at: http: / / www.koedoe.co.za

(C) 2010. The Authors. Licensee: OpenJournals Publishing. This work is licensed under the Creative Commons Attribution License.

\section{ABSTRACT}

South African National Parks (SANParks) plays a major role in the tourism industry and has three primary functions, namely to conserve biodiversity, to create tourism and recreational opportunities and to build strong community relations. These parks, therefore, have a definite socio-economic impact on adjacent communities, although little is known about this impact. The main aim of this study was to determine the socio-economic impact of Africa's oldest marine park, namely Tsitsikamma National Park, which forms part of the newly created Garden Route National Park. This was done by conducting three surveys during April 2008: a visitor's survey (156 respondents), a community survey (132 respondents) and a business survey (11 respondents). We found that the park has a positive economic impact on the surrounding area and that the community exhibits a favourable attitude towards Tsitsikamma National Park. The results also differed when compared to similar studies conducted at other national parks in South Arica and one of the main reasons for this was that the park is located in a touristic area. For a greater impact however, the park should expand its marine activities, while communication with the local community could also be improved.

Conservation implications: Good community relations and ecotourism activities are important components of good conservation practices. This research indicates that tourism activities not only generated funds for conservation, but also benefited the local communities of Tsitsikamma National Park. The positive attitude of local communities makes conservation of biodiversity more sustainable.

\section{INTRODUCTION}

Situated on the Garden Route in the Eastern Cape Province of South Africa, Tsitsikamma National Park (TNP) is Africa's oldest marine park (Figure 1). Tsitsikamma means 'place of much water' in Khoi-San and incorporates the wide Storms River mouth as well as $80 \mathrm{~km}$ of rocky coastline (including marine life and a variety of fauna and flora), spanning into the Indian Ocean (Maree 2007:2-8).

The World Conservation Union (IUCN) appealed to governments for the establishment of marine parks and reserves during the First World Conference on National Parks in Seattle in 1962. In response, TNP was proclaimed in December 1964 as the first national marine park in Africa by the then National Parks Board (Government Gazette 1964). The original coastal park extended approximately $59 \mathrm{~km}$ between

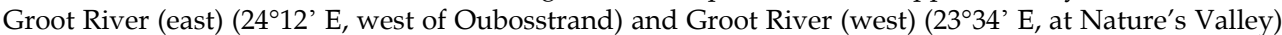
and included the areas within the region of $800 \mathrm{~m}$ landward and $800 \mathrm{~m}$ seaward of the low water mark (the horizontal distance was used and contours were ignored). In September 1983, the seaward boundary of the park between the Groot River (east) and the Bloukrans River (2339' E) was extended to three nautical miles. The remainder from Bloukrans to Groot River (west), was changed to half a nautical mile offshore (Government Gazette 1983). In December 1987, the De Vasselot Reserve (2561 ha) was added to the park (Government Gazette 1987).

The Park offers activities such as swimming, diving, snorkelling, hiking, short boat cruises and marine pond explorations. As a very popular ecotourism attraction in South Africa, the park attracts a considerable number of tourists annually (155 762 in the year ending March 2009) and has an influence on the economic and social well-being of the surrounding community. South African National Parks (SANParks) has three primary objectives, namely to conserve the biodiversity of the country, to promote community upliftment and capacity building among people living in the areas neighbouring the parks and to provide tourism and recreational outlets that allow people to experience and enjoy the wonders of the parks (Streuders 2008). This research focuses on the second and third objectives as the socio-economic impact of TNP has not yet been determined. In fact, no socio-economic study has been conducted on marine parks in South Africa; the reason being that it is difficult to understand and incorporate the role of local communities in park structures, even though the importance thereof has long been realised. Telfer and Sharpley (2008:6) refer to socio-economic development as the creation and improvement of wealth and employment, as well as an improvement in the accessibility of resources.

The aim of a socio-economic study is therefore to measure socio-economic development (Figure 2), usually in terms of improvements in metrics such as Gross Domestic Product (GDP), life expectancy, employment opportunities and how these improvements impact on a community's quality of life (Anon 2006). From a socio-economic point of view, there are four major relationships to be managed, and at a later stage, determined (Saayman, Saayman, Ferreira 2009a:1, Massyn 2008:225-236; Relly 2008:267-280). These relationships are reflected in Figure 2 and add to the importance and relevance of conducting a socio-economic study. Streuders (2008:45), Ferreira (2008) and Van der Merwe (2008:44) highlighted that it is of utmost importance that role players seen (Figure 2) are continuously in consultation with one another in order to avoid problems and conflict as well as to encourage socio-economic development, which may ultimately contribute to an improvement in the quality of life of communities, tourists and businesses. The economic contribution of a park is thus not the only important factor, but also the contribution the park makes towards the community's quality of life (Saayman \& Saayman 2006:3) and how these are integrated into SANParks' three primary objectives. 


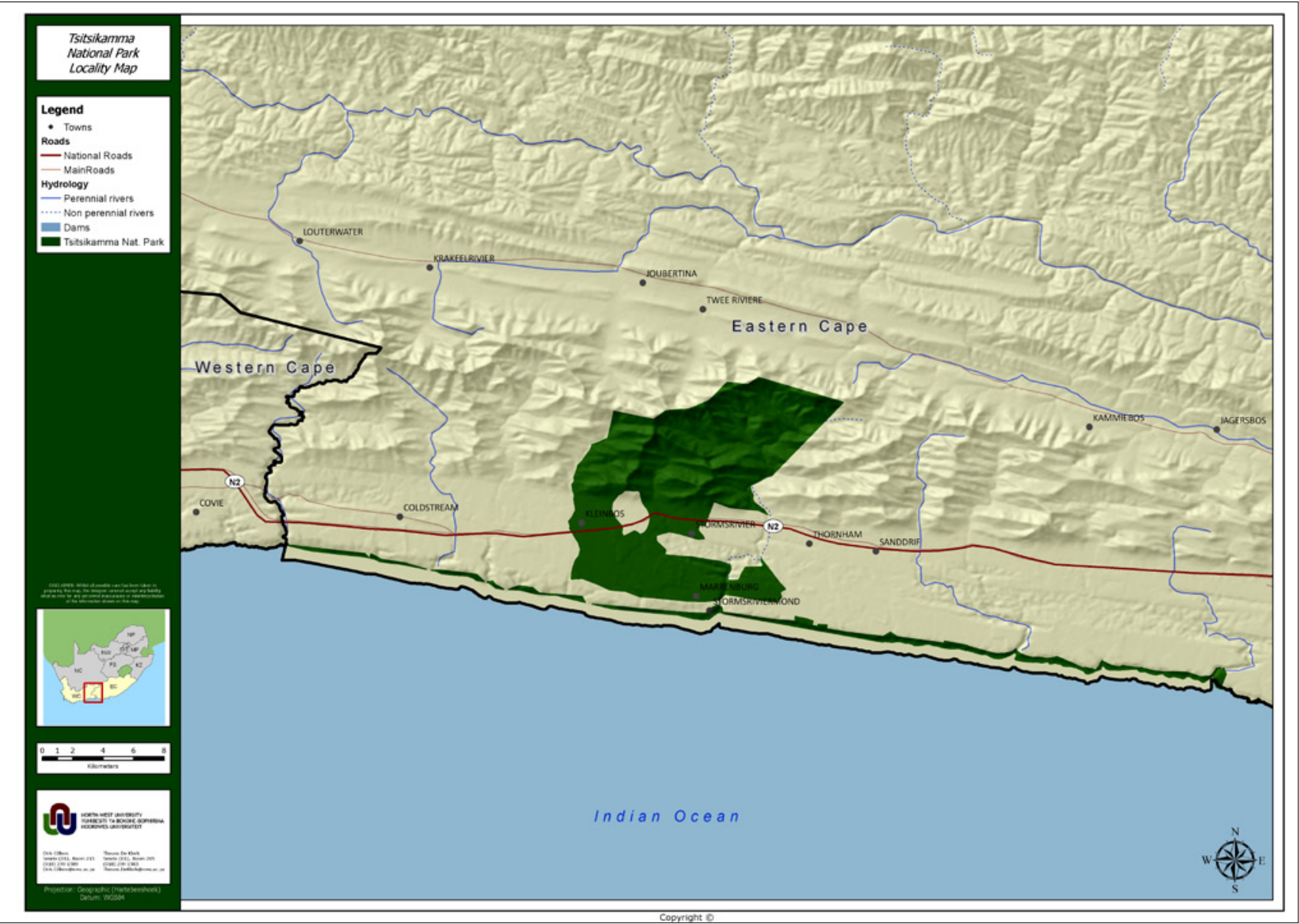

FIGURE 1

Location of Tsitsikamma National Park

Conservation plays a major role in the sustainability of the parks; however, parks have now become more reliant on tourism to sustain their existence; this reliability on tourism has both a positive and negative impact on the community (Ferreira 2008; Massyn 2008; Myburgh \& Saayman 2002:259; Streuders 2008). A higher level of community participation is needed wherein the community interacts directly with the environment and hopes to reap certain benefits from these interactions (Streuders 2008:113-114). The rights of the communities need to be acknowledged, including participation in decision-making, sharing in the benefits of development (e.g. job opportunities) and an enhancement of quality of life as a result of environmental improvements (Hall \& Richards 2000:103; Spenceley 2008:110). Streuders (2008:113-114) found that not all communities understand the relevance of a national park and that without the input of the community, park management will not be aware of community needs or know how to fulfil them. In addition, communities also need to understand the economic contribution and value of a national park.

When well managed, within the socio-economic framework tourism has various positive effects on communities, such as economic development, additional employment, the enhancement of community image, improved communitytourist relationships, cultural opportunities and increased community participation (Shone \& Parry 2004:54). However, Tiyce and Dimmock (2000:223-229) indicate that negative social impacts may include transformation in community characteristics and image as well as an increase in noise pollution and overcrowding. In terms of the economic impact, money spent by tourists has a multiplier effect within the local and regional economy, whereby income generated by the park can help in funding other activities such as nature conservation. On the other hand, the job opportunities created are often poorly paid and may lead to the occurrence of leakages (i.e. skills, products and services obtained from outside the region).

TNP is situated in a rural area which means that the degree of economic benefit depends on the amount of money that remains in the region. Leakages, in the form of imported skills and goods, pose a serious threat to the region's economic stability. These leakages will reduce the money remaining in the region and will greatly affect the economic benefits received by local communities. In determining the magnitude of TNP's economic impact, determinants such as location and size of the park, the number of tourists, their length of stay and how much they spend are important because they directly influence these leakages (Van der Merwe 2008:49).

Based on these observations, the following questions need to be asked when conducting a socio-economic study:

- What is the economic (monetary) value of the park, in terms of what tourists and park management spend?

- How many jobs are created by the park?

- What is the multiplier effect - in other words, how does the money spent in this particular region circulate through the region in order to create output and income for the community?

- What are communities' perceptions of the park and do they benefit from the park in general?

Inevitably, local communities experience social and cultural changes ascribed to tourism development. As quoted by Telfer and Sharpley (2008:199), previous studies by Dogan (1989), Ap and Crompton (1993), Costa and Feronne (1995), Williams and Lawson (2001), Kuvan and Akan (2005) and Spenceley (2008) found that local communities' attitudes towards tourists 


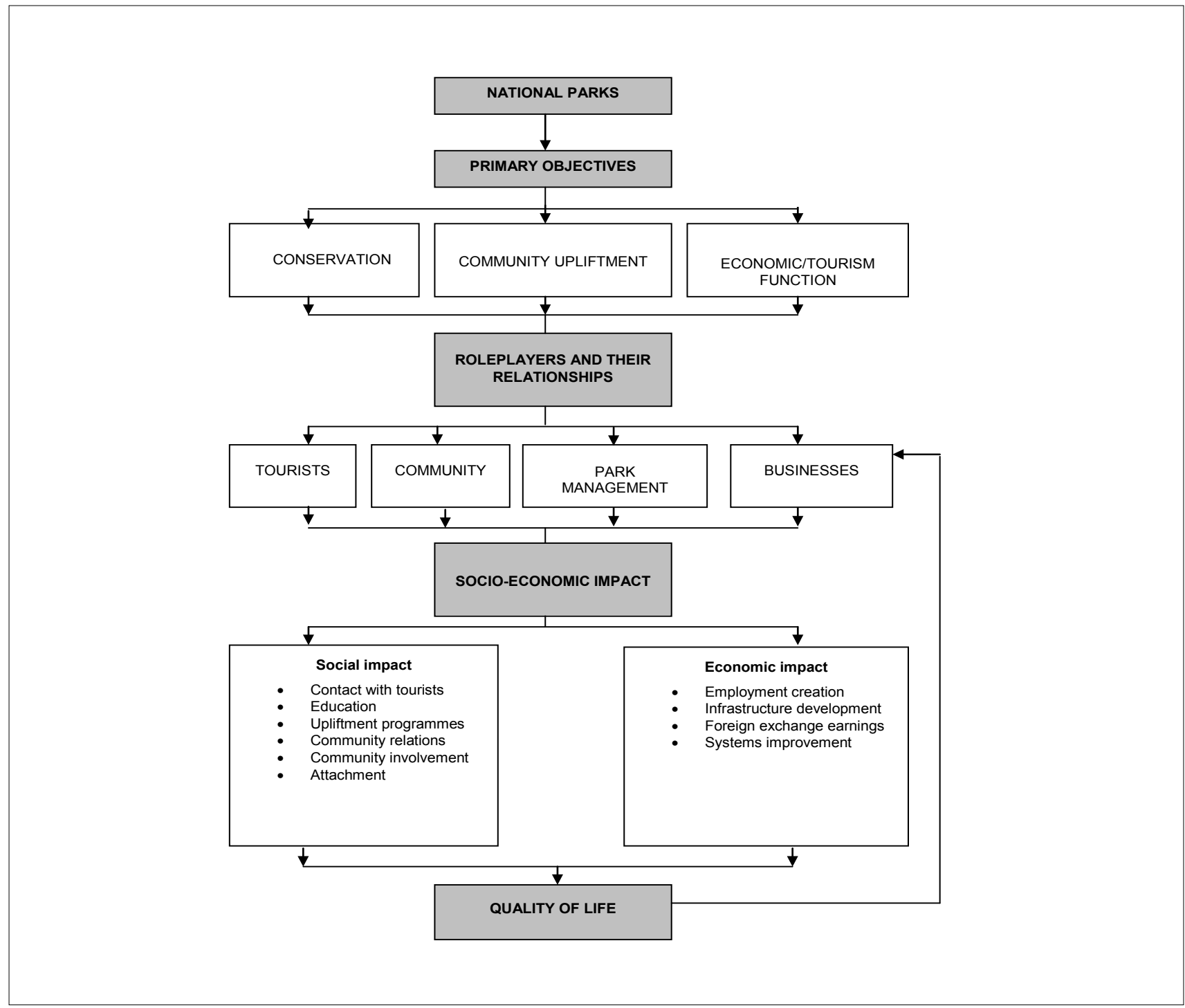

Sources: Ferreira (2008), Massyn (2008), Relly (2008), Saayman et al. (2009a), Streuders (2008), Van der Merwe (2008)

FIGURE 2

Conceptual framework for socio-economic research in National Parks

range from one of welcoming to one of disregard. The studies investigated how members of small communities perceive tourism, as well as which issues they have identified as being important such as personal values. Most found that tourism was regarded in a positive light and that community members exhibit a favourable attitude towards tourism development. However, it was also found that community members were concerned about the negative impacts of tourism. Green (2005) and Simpson (2008) found that changes within the community as a result of tourism were perceived as negative and that the focus of future tourism development should fall on sustainable development. Community involvement was identified as a key success factor for advantageous tourism development.

Samuelsson and Stage (2007), Relly (2008), Suich, Busch and Barbancho (2005), Mahony and Van Zyl (2002) and Gössling (2001) conducted studies concerning the economic impact of tourism on the community. Their findings indicated that tourism had a positive effect on local communities by improving their livelihood. According to their results, small-scale high-value tourism is important in maximising a long term stable income. Therefore, the local communities need tourism and tourism needs the local communities' support in order to be sustainable.

Other socio-economic studies have been conducted, including investigations into the Okavango Delta in Botswana (Mbaiwa
$2003,2004,2005)$, a socio-economic impact study of hunting in the Northern Cape Province of South Africa (Van der Merwe, Saayman and Rossouw 2009), the Klein Karoo National Arts Festival (Van der Merwe 2008), Turco et al.'s (2003) investigations into the socio-economic impact of sport tourism in Durban, as well as a study by Sims-Castley et al. (2005), which determined the significance of an ecotourism-based private game reserve in the Eastern Cape Province of South Africa. According to these studies, tourism has contributed positively towards the development of communication facilities and infrastructure and has increased tourist-flow. Therefore, for successful and sustainable tourism development to occur, it is important to focus on how tourism impacts on social equity, economic efficiency and on ecological sustainability of local communities. Loader (1994:143) and Pelser (2003:164) state that in South Africa social involvement is an integral part of conservation. In the case of the residents of the Kepulauan Seribu Marine Park in Del Este in the Dominican Republic, Macleod (2001:221), Fauzi and Buchary (2002:167) suggest that poverty should be improved; residents should be the main concern and park management should be based on the agreement and involvement of all stakeholders. The problem with most of these studies is that, firstly, their methodologies differed significantly thereby making it difficult to compare their results. A reason for this is that researchers attempt this kind of research from different perspectives, including: sociology, investment, economics, conservation, pro- 
poor tourism, responsible tourism, ecotourism and sustainable tourism, according to their different fields of expertise and interest. Secondly, the fact that the study areas (i.e. products) differed had significant implications for each set of results; some studies were conducted in wetlands, in national parks, in game farms and in private parks. The importance of these results lies in the aims and objectives of these different offerings (i.e. products). Thirdly, few studies had specific multipliers; Relly (2008) states that determining multipliers could provide an indication in terms of the impact of a park on the poor. Finally, Ferreira (2008) states that most so called 'socio-economic studies' are, in fact, economic analyses, with little or no social impact analyses other than a reference to employment. Again, Ferreira (2008) supports the notion that socio-economic studies have to be more comprehensive.

Only two socio-economic studies have been conducted at national parks in South Africa, namely Karoo National Park (Saayman et al. 2009a) and Addo Elephant National Park (Saayman \& Saayman 2006). Both of these studies found that these parks had a positive socio-economic impact, although their results differed significantly. These differences were ascribed to aspects such as the size of the park, type of activities available, number of tourists, variety of animals and plants found in the park, involvement of the community in the park management and levels of poverty in communities adjacent to the park. The question remains whether a marine park will have different results and what lessons can be learnt from the socio-economic impact of a marine park. Therefore, results from this study could assist SANParks in achieving its objectives more efficiently, as well as contribute to the existing knowledge of socio-economic studies in national parks. The aim of this research was to estimate the socio-economic contribution of TNP to the surrounding communities which involved estimating the economic impact of TNP on the local economy, estimating the impact of tourism business development in the region along with how these businesses and communities benefit from the park and finally, determining the employment generated as a result of the tourism activity generated by the park.

\section{METHODS}

When conducting socio-economic studies, three controversial issues need to be addressed (Gelan 2003), namely, (1) which monetary spending to include, (2) designating the study area, and (3) determining what multipliers to use. For this study, we assessed both park expenditure and expenditure by visitors, in order to determine the economic value of TNP to the region. Secondly, we defined the local economy as the $20-\mathrm{km}$ radius around TNP, which meant that the study area included the communities of Nature's Valley and Storms River Village. Storms River Village is a fairly poor community, with $25 \%$ of the local residents being unemployed and $11 \%$ being pensioners or self-employed. Nature's Valley, however, is a fairly well-off community, although most of the houses are holiday or second homes.

Three surveys were conducted to achieve the goal of this study, (1) a community survey among the local residents of Nature's Valley and Storms River Village to measure the social impacts, (2) a business survey, including permanent local businesses in and around the park and (3) a visitor survey of tourists going to the park in order to measure the economic impacts that increase as a result of the park's presence in the region. Partial multipliers were derived through a process of iteration to determine the economic impact of TNP. Vaughan, Farr and Slee (2000) proposed proportional multiplier analysis in determining the local economic impact of visitors' spending on a rural national park. Two methods can be used to derive these multipliers, namely a process of iteration or a partial input-output model. Because of a limited number of firms in the study area, a process of iteration was used where the spending is traced through the local economy as tourists buy goods and firms buy stock from suppliers and pay their employees. The multipliers thus represent the change in sales and income that results from tourist spending.

\section{Multiplier iteration}

The multiplier iteration procedure can occur in a number of ways. One example is when a tourist purchases accommodation services from a hotel, guest house or lodge. The owner of the accommodation service uses the money received to pay for various expenses, including goods such as soap, towels and breakfast provisions. The portion spent on goods is then traced to the providers of these goods (e.g. supermarkets). Supermarkets use the received money to make certain payments (e.g inventory). This portion of the money is then traced towards the providers of inventory (i.e. wholesalers and producers), who use the funds received to pay their own expenses. As an example, producers would use a portion of the money to pay for raw materials, a payment which can then be traced to the provider of those raw materials. The sum of these payments to the various role players constitute the increase in total output due to the purchase of accommodation by the tourist and thus the output multiplier is derived by dividing the sum of these payments by the original payment made by the tourist. This process requires detailed information from businesses, which was provided by the business survey.

Six postgraduate students assisted in distributing the questionnaires to the selected groups between 25 and 29 March 2008. These field workers distributed the questionnaires and collected the completed questionnaires later in the evening. The data were then coded and captured on Microsoft Excel 2007, and the analyses were done using both SPSS v.15 and Microsoft Excel. Descriptive analyses were conducted in order to provide preliminary insights into the nature of the responses obtained, as reflected in the distribution of the values of each variable of interest (Tustin et al. 2005:341).

\section{Community survey}

Community data were obtained by means of a structured questionnaire based on the social impact measuring instrument developed by Fredline, Deery and Jago (2003:29). The reason for using this instrument is twofold: firstly, it is frequently used to determine the social impact of tourism on a community and, secondly, it allows for easier comparison of results from different studies. This instrument was adapted from a festivalbased study for which the instrument was originally designed according to the needs of this nature-based product. Residents' perceptions (i.e. the main variables for the purpose of this study) were measured using a 3-point or 4-point Likert scale. The scales used by Fredline et al. (2003) were retained and independent variables, such as community attachment, participation and length of stay, were also measured by means of closed-ended questions.

There are approximately 360 households (with 91 permanent households) in Nature's Valley and 470 in Storms River Village and can therefore be considered small towns. This led to the decision to include all households in the sample frame. The initial part of the study was based on probability sampling, where each element in the population had a known, non-zero probability of being included in the sample (Tustin et al. 2005:344). Availability sampling was therefore implemented and residents who were willing and available to complete the questionnaire formed part of the final sample. In total, 132 questionnaires were completed even though field workers experienced problems such as encountering inaccessible and/or vacant houses.

\section{Business survey}

In this study, a questionnaire similar to the one used for determining the socio-economic impact of the Karoo and Wilderness National Parks was implemented (Ferreira 2008). 
TABLE 1

The influence of the Tsitsikamma National Park on the community

\begin{tabular}{|c|c|c|c|c|c|c|c|}
\hline \multirow[t]{2}{*}{ Statement } & \multicolumn{2}{|c|}{ Very negative } & \multicolumn{3}{|c|}{$\stackrel{\longrightarrow}{\longrightarrow}$} & \multicolumn{2}{|c|}{ Very positive } \\
\hline & 1 & 2 & 3 & 4 & 5 & 6 & 7 \\
\hline Personal quality of life & $6 \%$ & $2 \%$ & $3 \%$ & $15 \%$ & $9 \%$ & $21 \%$ & $44 \%$ \\
\hline Nature's Valley and Storms River Village & $7 \%$ & $2 \%$ & $1 \%$ & $14 \%$ & $8 \%$ & $18 \%$ & $50 \%$ \\
\hline
\end{tabular}

Again, availability sampling was applied and all businesses in the specified area were included in the sampling frame. However, only those who were willing and available to complete the questionnaire participated. Thirty five questionnaires were distributed to businesses operating within the survey area. In total, only 11 questionnaires were completed and used for our study.

\section{Visitors' survey}

The visitors' survey was based on a questionnaire that has been used since 2001 in various national parks. Questions focused on the demographic aspects and expenditure of the park visitors in order to obtain the socio-economic information needed to conduct this study. A convenience sampling was drawn from the visitors to TNP between 25 and 29 March 2008. Field workers distributed the questionnaires among overnight visitors and 156 questionnaires were completed for the purpose of this study: 80 by visitors in campsites and 76 by visitors in chalets. The number of questionnaires was deemed representative of the total population seeing that the surveys conducted since 2001 were done in different months and therefore different seasons. Saayman and Fouche (2007:26) also indicated that the profile of the visitors to TNP had remained consistent since 2001 and that the sample could be seen as representative.

\section{RESULTS}

The results are divided into two sections and discussed below. The first section covers the social impact results that were obtained through the community survey and the second section indicates the economic impact results that were obtained from both the business and visitor surveys.

\section{Social impacts}

Sustainable socio-economic development is influenced by community perceptions. It is important that the community members of Nature's Valley and Storms River Village respond positively towards TNP and the management thereof. Statements were rated by using a 7-point Likert scale where 1 is very negative and 7 is very positive (Table 1 ). Respondents indicated that TNP has a very positive impact on the community of Nature's Valley and Storms River Village (68\%). TNP also affects the community's personal quality of life in a very positive manner $(65 \%)$

When considering specific perceptions (Table 2) of the community, respondents indicated that (i.e. the sum of the percentage of respondents who chose 3 and 4 on the Likert scale) TNP contributes to the increased number of tourists visiting the area $(81 \%)$, sustains the environment $(80 \%)$ and conserves the natural resources $(80 \%)$. In contrast, however, community members feel that, because of TNP's presence, the prices of some goods and services have increased $(76 \%)$ and that less parking is available during high season $(71 \%)$. In general, TNP is seen as contributing to the development of the area and community members consider the park as an asset. However, it is imperative to get community members more involved in park management and park management should continue to maintain positive relationships with these communities.

\section{Economic impacts}

Visitors to TNP can be grouped into two broad categories, namely day visitors and overnight visitors. Seeing that the park offers both camping facilities and chalets, the overnight visitors are divided further into campers and visitors who overnight in chalets. The magnitude of economic impact depends on (1) the number of visitors to the park, (2) the magnitude of their spending while visiting the park and (3) the effect of their spending on the generation of additional output and income in the area surrounding the park; this occurrence is referred to as the multiplying effect.

Firstly, there was a steady decline in the number of visitors to TNP between 2003 (203 678 visitors) to 2006 (162 549 visitors). However, visitor numbers appear to have increased since 2007, with a total of 177722 tourists visiting the Park during 2008. This decline can mainly be ascribed to a decline in chalet unit nights sold until 2005 (declining to a low of 22655 chalet nights sold), while 2006 showed a large decline in camping nights sold (38 890 nights, compared to the 50876 nights in 2005). In this case, 2006 was clearly an atypical year in the park's history. In 2008, a total of 60236 camp person nights were sold, while 24655 chalet unit nights were sold.

The visitor survey revealed that campers visiting TNP travel in groups averaging 3.4 people, while visitors staying in chalets travel in groups averaging 3.6 people. This information is valuable because camping numbers are in 'person nights'. This is also an interesting observation seeing that campers generally tend to travel in larger groups when visiting other national parks (see Saayman, Fouché \& Kruger 2009b).

Secondly, to determine the magnitude of spending by tourists the visitor survey was again conducted. Spending was grouped into the selected sectors used in the iteration process. According to the survey, campers spent, on average, R2707.45 while staying at TNP. This amounted to R530.87 per group per day. Spending of chalet tourists was on average R3194.80 per group, exceeding that of campers and resulted in chalet tourists spending R887.44 per day per night per group. The spending patterns of campers differed from those of visitors in chalets, with campers spending a relatively higher percentage on food and restaurants than visitors in chalets (Table 3). However, for both campers and chalet visitors, spending on accommodation, food and restaurants amounted to approximately $80 \%$ of their total spending, with very little being spent on curios. Transport to TNP was excluded from the analysis because it could not be ascertained where or how frequently the visitors filled their car with petrol or which transport company was used. Owing to the fact that accommodation is paid to the SANParks head office in Pretoria, this figure was also subtracted from the spending of tourists. The portion of accommodation spending that accrues to TNP is included in the budget of park management.

Approximately $74 \%$ of respondents indicated that they also spent money in the area outside TNP. The businesses most visited by the respondents were petrol stations, general dealers (i.e. retail and food), restaurants and liquor stores.

SANParks provided the income and expenditure account for TNP for the year ending March 2008. According to this account, expenditure, excluding depreciation, amounted to approximately R15 million. A rough breakdown of these costs revealed that the highest spending item was personnel $(56.5 \%)$, followed by operational costs $(31 \%)$ and maintenance $(12.5 \%)$. To allocate these cost items to the various sectors in the model, some assumptions were made, including that $90 \%$ of operational expenses did not take place in the area surrounding the park, with the remainder bought from retailers. Only 50\% of maintenance cost accrued to the local economy and was 
TABLE 2

Perceptions concerning Tsitsikamma National Park

\begin{tabular}{|c|c|c|c|c|}
\hline \multirow[t]{2}{*}{ Social indicators } & \multirow{2}{*}{$\frac{\text { Totally disagree }}{1}$} & \multicolumn{2}{|c|}{$\longleftrightarrow$} & \multirow{2}{*}{$\begin{array}{l}\text { Totally agree } \\
4\end{array}$} \\
\hline & & 2 & 3 & \\
\hline The appearance of the area has improved & $6 \%$ & $20 \%$ & $56 \%$ & $18 \%$ \\
\hline Nature resources of the area are conserved & $3 \%$ & $11 \%$ & $59 \%$ & $21 \%$ \\
\hline Noise levels in the area have increased & $16 \%$ & $37 \%$ & $42 \%$ & $5 \%$ \\
\hline Employment opportunities in Nature's Valley/Storms River have increased & $9 \%$ & $18 \%$ & $57 \%$ & $16 \%$ \\
\hline The range of things to do in Nature's Valley/Storms River has increased & $8 \%$ & $25 \%$ & $51 \%$ & $16 \%$ \\
\hline The number of people in the area has increased & $5 \%$ & $16 \%$ & $58 \%$ & $21 \%$ \\
\hline Rowdy and delinquent behaviour has increased & $14 \%$ & $39 \%$ & $33 \%$ & $14 \%$ \\
\hline Property values in the area have increased & $10 \%$ & $25 \%$ & $48 \%$ & $17 \%$ \\
\hline Crime has increased & $19 \%$ & $35 \%$ & $36 \%$ & $10 \%$ \\
\hline Participation in community activities has increased & $11 \%$ & $24 \%$ & $56 \%$ & $9 \%$ \\
\hline Opportunities to relax have increased & $11 \%$ & $27 \%$ & $53 \%$ & $9 \%$ \\
\hline Prices of some goods and services have increased & $8 \%$ & $16 \%$ & $53 \%$ & $23 \%$ \\
\hline The pride that Nature's Valley/Storms River residents have in their town has improved & $15 \%$ & $21 \%$ & $50 \%$ & $14 \%$ \\
\hline The overall cost of living has increased & $10 \%$ & $28 \%$ & $41 \%$ & $21 \%$ \\
\hline Litter in the area has increased & $17 \%$ & $31 \%$ & $37 \%$ & $15 \%$ \\
\hline Damage to the environment has decreased & $12 \%$ & $23 \%$ & $50 \%$ & $15 \%$ \\
\hline Opportunities to meet new people have increased & $8 \%$ & $21 \%$ & $57 \%$ & $14 \%$ \\
\hline Opportunities for local business have increased & $10 \%$ & $27 \%$ & $51 \%$ & $12 \%$ \\
\hline The number of tourists visiting Nature's Valley/Storms River has increased & $6 \%$ & $13 \%$ & $58 \%$ & $23 \%$ \\
\hline Excessive drinking and/or drug use has increased & $17 \%$ & $38 \%$ & $38 \%$ & $7 \%$ \\
\hline $\begin{array}{l}\text { The number of people moving to Nature's Valley/Storms River permanently or buying holiday homes here has } \\
\text { increased }\end{array}$ & $12 \%$ & $19 \%$ & $56 \%$ & $13 \%$ \\
\hline Public funding for community activities has increased & $12 \%$ & $34 \%$ & $46 \%$ & $8 \%$ \\
\hline The rights and civil liberties of local residents have increased & $16 \%$ & $39 \%$ & $38 \%$ & $7 \%$ \\
\hline Roads and public facilities are better maintained & $23 \%$ & $23 \%$ & $47 \%$ & $7 \%$ \\
\hline Interactions between locals and tourists have improved & $15 \%$ & $20 \%$ & $59 \%$ & $6 \%$ \\
\hline Facilities available to local residents have improved & $14 \%$ & $34 \%$ & $47 \%$ & $5 \%$ \\
\hline Social and moral values have improved & $16 \%$ & $36 \%$ & $42 \%$ & $6 \%$ \\
\hline The natural resources of the area are being over-used & $18 \%$ & $35 \%$ & $42 \%$ & $5 \%$ \\
\hline Property prices have increased & $10 \%$ & $22 \%$ & $53 \%$ & $15 \%$ \\
\hline More investors are focusing on development in Nature's Valley/Storms River & $9 \%$ & $19 \%$ & $57 \%$ & $15 \%$ \\
\hline Investment opportunities are limited & $11 \%$ & $38 \%$ & $44 \%$ & $7 \%$ \\
\hline The natural environment has been sustained since the establishment of the park & $7 \%$ & $13 \%$ & $61 \%$ & $19 \%$ \\
\hline During high season the availability of parking decreases & $8 \%$ & $21 \%$ & $53 \%$ & $18 \%$ \\
\hline During high season traffic congestion in the area increases & $7 \%$ & $25 \%$ & $56 \%$ & $12 \%$ \\
\hline During high season the turnover for local businesses increases & $9 \%$ & $21 \%$ & $52 \%$ & $18 \%$ \\
\hline
\end{tabular}

TABLE 3

The spending patterns of campers and visitors in chalets

\begin{tabular}{|c|c|c|c|c|}
\hline Spending category & Visitors camping & Percentage & Visitors in chalets & Percentage \\
\hline Accommodation & R1235.00 & $45.60 \%$ & R1869.38 & $58.50 \%$ \\
\hline Food and restaurants & R855.06 & $31.60 \%$ & R711.20 & $22.30 \%$ \\
\hline Tourism services & $\mathrm{R} 258.91$ & $8.70 \%$ & R244.14 & $9.40 \%$ \\
\hline Retail & $\mathrm{R} 235.14$ & $8.70 \%$ & $\mathrm{R} 300.70$ & $9.40 \%$ \\
\hline Transport & $\mathrm{R} 122.46$ & $4.50 \%$ & R69.38 & $2.20 \%$ \\
\hline Total & R2707.45 & $100 \%$ & R3194.80 & $100 \%$ \\
\hline Total excluding transport & R2584.99 & & R3125.42 & \\
\hline Total excluding accommodation & R1349.12 & & R1256.04 & \\
\hline
\end{tabular}

equally divided between retail and other service providers (such as electrical services); no finance costs accrued to the local area because the nearest bank branches are located in Plettenberg Bay in the Western Cape.

As unit nights already excluded the problem associated with 'spending per person' versus 'spending per group', only the numbers of campers were divided by the average group size for campers (i.e. 3.4 people) and the average length of stay (i.e. 5.1 nights) in order to estimate the camper groups. According to this method, 3474 camper groups visited the Park during 2007 and 2008. To determine the number of chalet visitors, the unit nights sold were divided by the number of days that a group stayed (i.e. 3.6 days); the result was 6849 groups or chalet visitors. The magnitude of visitor spending was calculated by multiplying the number of groups with the above estimates and the average spending per visitor group, excluding transport cost (Table 3).
This calculation revealed that total spending by visitors staying in chalets amounted to approximately R8.6 million, while the total spending by camping visitors amounted to approximately R4.7 million. Total visitor spending during 2008 was therefore estimated at approximately R13.3 million.

Thirdly, the multiplier effect of the spending by visitors was determined. Two methods can be employed to determine the multiplier impact on the local economy, namely iteration and matrix inversion (Vaughan et al. 2000). The authors decided to use iteration, since the local economy surrounding Tsitsikamma National Park is limited and has no municipal, manufacturing or wholesale sectors. In terms of output, one additional chalet tourist group (change in demand) in each category created an additional output of R1400.49, indicating an output multiplier of 1.11. One additional camping group created an additional output of R1510.78, indicating an output multiplier of 1.12. The 
TABLE 4

Total impact of the Tsitsikamma National Park on the local economy

\begin{tabular}{llll}
\hline Category & Total spending & Ouput effect & Income effect \\
\hline Chalet & R8 602 665 & R9 505 944 & R2 580 800 \\
Camp & R4 686 843 & R5 202 396 & R1 499 790 \\
Park & R14 973 528 & R16 470 881 & R12 428 028 \\
\hline Total & R28 263 036 & R31 179 221 & R16 508 618 \\
\hline
\end{tabular}

multipliers created by the iteration process are in line with those determined for Addo Elephant National Park, but the multiplier is much smaller than that for Karoo National Park. The latter was expected because the towns near TNP are less diversified and industrially developed than Beaufort West in the case of Karoo National Park.

To determine the total effect on income (i.e. direct, indirect and induced), the process had to be expanded to include the effect of household spending and wages. The assumption was made that the consumption pattern of locals in the study area is similar to that of the national consumption pattern as defined in the 2004 nationwide Social Accounting Matrix (Coningarth Consultants 2006). It is evident that spending directly translates into income for a business and as the business expands its production, the income of other businesses also expands. This iteration process captures the direct and indirect effects of income for businesses; however, not all income received by businesses translate into income for consumers. Income is used to buy stock, to pay for operational expenses and services and to pay labourers. Once these payments have been made, it is possible to ascertain whether or not profit has been made. It is integral to reach a point where profit is turned consistently in order to determine how the spending by tourists and park management can be translated into income for consumers (i.e. households) in the Tsitsikamma area.

The income multiplier generated by the iteration process for people holidaying in chalets was 0.57 and 0.62 for campers, indicating that one additional chalet group generated income of R716.70 for the immediate economy and one additional camping group generated income of R845.92. These multipliers are in line with those found for Addo Elephant National Park, but they are lower than the income multipliers of Karoo National Park. It is interesting to note that the effect of one camping group is greater than that of tourists staying in chalets. One of the reasons might be that campers spend money on a wider variety of products and services in the local economy.

While these estimates reflect the spending by visitors, they do not indicate the operational spending of TNP. If a similar process is repeated for park expenditure, the output multiplier is found to be 1.10 , while the income multiplier is 0.27 . These income effects now exclude the income paid to its employees by the park; therefore, the total income effect of park expenditure was adapted to include both the direct, indirect and induced income effects of park expenditure. The total impact of the Park on the local economy is indicated in Table 4.

The number of years in which the different businesses have been operational provided a good indication of how businesses evolved in the region. Isolating the influence of TNP is a nonaccomplishable task, because tourist activity along the Garden Route (which is the park's location) has increased significantly; the area is renowned for its scenic beauty and tourism potential.
However, it is interesting to note that none of the businesses in the area is older than TNP. It is evident that the tourism service industry (especially recreational activities in the area) only started to boom in the past few years. As could be expected, many businesses indicated that they rely heavily on tourist spending (Table 5) seeing that the area boasts a thriving tourism destination for both locals and foreigners. Table 5 presents a breakdown of the businesses in the area that completed the business survey, as well as an indication of the employment levels and the number of permanent versus part-time personnel.

As indicated in Table 5, the accommodation industry is extremely reliant on labour and employs a significant number of people in the area; approximately 118 people were employed by the accommodation units surveyed. It should also be noted that, in all the cases except for one particular retailer with three employees, the workers employed lived in the area. This is encouraging because it is an indication that employment opportunities are created for the local community.

On average, accommodation establishments sold $81 \%$ of their business to tourists and $19 \%$ to locals. It should be kept in mind that some of the accommodation units also offer other products (such as a restaurant or small retail outlets) which may have contributed to the relatively high percentage of turnover ascribed to the area's locals. Tourists are also the main customers of tourism and recreation services, while restaurants, food stores and retailers are reliant on both tourist and local business for their existence. This is indicated in Table 5 and again highlights the importance of the tourism industry as a source of employment and income in the local economy surrounding TNP.

The accommodation establishments indicated that they owed $35 \%$ of their turnover to TNP, while $12 \%$ of retail turnover was ascribed to the park. Owing to a lack of additional information, we assume that the same percentages indicated in previous studies can be applied to TNP for the restaurant $(7.5 \%)$ and tourism and recreation services (33.3\%). If this is taken as an indication of the number of employment opportunities created because of the park, it can be concluded that the park led to the creation of 44 additional job opportunities within the businesses surveyed (i.e. presuming that a linear relationship between turnover and employment exists); TNP alone employs 86 people.

This survey captured 157 beds as part of the accommodation sector, while the Tourism Association indicated that there were 620 beds available. Thus, approximately $25 \%$ of the accommodation products were surveyed with the extrapolation of the employment results indicating that 176 additional jobs were created by TNP. Including the park employment figure, total employment for the study area was 262. Considering the 561 households in Storms River Village and Nature's Valley, it can be concluded that the tourism industry, sparked by the presence of TNP, provides employment opportunities for approximately $46.7 \%$ of all the households, which confirms that the area is very reliant on tourism.

\section{DISCUSSION}

From the results of this study, it becomes clear that TNP has a positive socio-economic impact on the region. The results, specifically in terms of the perceptions of the local community, confirm research by Streuders (2008), Fauzi and Buchary (2002),

TABLE 5

Breakdown of businesses in the area and employment levels

\begin{tabular}{|c|c|c|c|c|c|c|c|}
\hline Type & Number & $\begin{array}{l}\text { Average number of } \\
\text { employees }\end{array}$ & Permanent & Part-time & Total employment & $\begin{array}{c}\% \text { Turnover due to } \\
\text { park }\end{array}$ & Tourist-local ratio* \\
\hline Accommodation units & 6 & 20 & 18 & 12 & 118 & $35 \%$ & $81: 19: 00$ \\
\hline Retailers & 4 & 3 & 2 & 1 & 11 & $12 \%$ & $35: 65$ \\
\hline Food and restaurants & 1 & 10 & 10 & 0 & 10 & Not indicated & $46: 54: 00$ \\
\hline Tourism services & 1 & 1 & 1 & 0 & 1 & Not indicated & $90: 10: 00$ \\
\hline
\end{tabular}

*This refers to the customer ratio of locals versus tourists. 
Macleod (2001), Dogan (1989) and Kuvan and Akan (2005) in that the communities, in general, perceive tourism development (in this case, TNP) as positive. Research by Spenceley (2008) and Simpson (2008) had mixed results in their respective studies concerning community participation. Results from this study also indicated that the park has a positive impact on the quality of life of adjacent communities which confirmed research by Macleod (2001), Saayman and Saayman (2006), Ferreira (2008), Streuders (2008), Mbaiwa $(2004,2005)$ and Saayman et al. (2009a). The newly established park forums should contribute to an even better relationship between TNP and adjacent communities.

The economic analysis also shows that the park has a positive impact thereby re-confirming the findings of Saayman and Saayman (2006) in the Addo Elephant National Park, as well as Saayman et al. (2009a) in the Karoo National Park; however, TNP indicated a more substantial economic impact than the Karoo National Park. Mbaiwa (2004, 2005), Spenceley (2008) and Relly (2008) also confirm that tourism and conservation areas in general have a positive economic impact and is highlighted by Relly's research in Madikwe, which clearly illustrated the significant impact of tourism investment in the area (Relly 2008). TNP, however, has a significant leakage: Tiyce and Dimmock (2000) stated that this is an aspect that has to be addressed if the region wants to take full advantage of TNP. The main reason for the high leakage is the dependence of the region on tourism and the absence of other major industries. This implies that most of the money spent in the area, immediately leaves the area when goods and services are purchased. Most of the stock in the area is therefore 'imported' from other regions. Therefore, it seems that the more dependent the regional economy becomes on tourism, the greater this leakage. The leakage in terms of immediate employment is lower because most of the employees live in the area. However, the high leakage of goods causes the positive impact on income generation and employment to be lower than it would be in a more diversified economy.

An overlooked opportunity revealed by this research is the low spending on curios. Perhaps the production of curious could become a joint venture between the park and the community in order to grow small industries which would assist in curbing leakages. Results also showed that TNP has directly contributed to the existence of $25 \%$ of the businesses in Nature's Valley and Storms River Village, which is higher than the $4 \%$ for Karoo National Park, but lower than the 35\% for Addo National Park. However, a much higher percentage of businesses indicated that tourism activity contributes significantly to their turnover. This might be an indication that the businesses in Nature's Valley and Storms River Village underestimate the impact of TNP on their activities.

A major contradiction revealed in terms of the literature presented in this study is that a larger park and greater variety of tourist activities and species lead to an increased socioeconomic impact when compared to terrestrial parks. TNP, however, is small compared to most terrestrial parks and offers few organised activities with only a small variety of species accessible to tourists; this proves that tourists are attracted to the region because of its natural beauty (especially in terms of the sea and shoreline). In addition, tourists stay longer at TNP than at the Karoo or Addo Elephant National Parks, even though these parks offer more activities and a wider variety of species. Results also indicated that chalet tourists spend more than campers, but that the campers' spending patterns affect more sectors of the economy. Therefore, both types of tourists are important from a socio-economic and marketing point of view. However, TNP should offer more marine activities (such as diving, boat rides, canoeing, etc.) because this could lead to greater tourist spending which will result in a greater socio-economic impact.

\section{CONCLUSION}

The purpose of this research was to determine the socioeconomic impact of TNP on the local communities. From the results, it has been confirmed that TNP has a positive socio- economic impact on the communities of Nature's Valley and Storms River Village. The positive impacts are evident in direct tourist spending, job creation, a wide variety of social indicators and business development in the area. A negative aspect, however, is high leakage from the regional economy. The TNP is therefore achieving its conservation goals, creating economic opportunities and involving the community.

An aspect not covered by this research is the cost of economic opportunities that were lost to make way for the park. This would be difficult to determine and should be seen in the context of the government mandate to conserve $10 \%$ of land in South Africa which includes all types of biomes; however, government's goal has yet to be achieved. If this level of conservation is not achieved, South Africa's biodiversity will become impoverished and will necessitate the protection of more land, including marine areas.

From the results, it appears that TNP has a balanced approach in terms of its three main objectives. The area is dependent on tourism, which leads to high leakages which is an aspect that requires urgent attention. However, solutions will depend on cooperation between the park, communities and businesses in the region. In this regard, the results from this study contradict some findings compared to similar research at terrestrial parks where leakages were lower. The marine attributes of TNP are a strong enough attraction to ensure that tourists stay longer than at Karoo and Addo Elephant National Parks, confirming the importance of a marine park. This study suggests that marine conservation is highly valued by communities and should therefore be maintained by ensuring a high quality of water, the creation and maintenance of natural habitats for animals as well as a pollution-free environment.

\section{ACKNOWLEDGMENTS}

We thank SANParks and especially Mr Glenn Phillips and Mr Joep Stevens for funding, as well as information used in this study. The National Research Foundation is acknowledged for funding. We thank Dr Anna Spenceley, the anonymous reviewers and the language editor for valuable comments and suggestions.

Editor: Anna Spenceley

\section{REFERENCES}

Anon., 2006, 'Section on socio-economics newsletter of the Association of American Law Schools', Journal of Law and Socio-economics 27, Dec.

Ap, J. \& Crompton, J.L., 1993, 'Residents' strategies for responding to tourism impacts', Journal of Travel Research 32(1), 47-50.

Conningarth Consultants, 2006, 'Disaggregated social accounting matrix for South Africa', Unpublished Report delivered as part of a research project commissioned by the Development Bank of Southern Africa, Pretoria.

Costa, J. \& Ferrone, L., 1995, 'Socio-cultural perspectives on tourism planning and development', International Journal of Contemporary Hospitality Management 7(7), 27-35.

Dogan, H.Z., 1989, 'Forms of adjustment: Sociocultural impacts of tourism', Annals of Tourism Research 16(2), 216-236.

Fauzi, A. \& Buchary, E.A., 2002, 'A socioeconomic perspective of environmental degradation at Kepulauan Seribu Marine National Park, Indonesia', Coastal Management 30(2), 167-181.

Ferreira, M., 2008, 'The socio-economic impact of tourism in the Karoo National Park', MCom thesis, School of Business Management, North-West University.

Fredline, E., Deery, M. \& Jago, L., 2003, 'The development of a generic scale to measure the social impacts of events', Event Management 8(1), 23-37. 
Gelan, A., 2003, 'Local economic impacts: The British Open', Annals of Tourism Research 30(2), 406-425.

Gössling, S., 2001, 'Tourism, economic transition and ecosystem degradation: interacting processes in a Tanzanian coastal community', Tourism Geographics, 3(4), 430-453.

Government Gazette, 1987, viewed 28 January 2010, from http:// www.sanparks.org/parks/garden_route/camps/storms_ river/tourism/history.php

Green, R., 2005, 'Community perceptions of environmental and social change and tourism development on the island of Koh Samui, Thailand', Journal of Environmental Psychology 25(1), 37-56.

Hall, D. \& Richards, G., 2000, Tourism and sustainable community development. Routledge, Abingdon.

Kuvan, Y. \& Akan, P., 2005, 'Residents' attitudes toward general and forest-related impacts of tourism: The case of Belek, Antalye', Tourism Management 26(5), 691-706.

Loader, J.A., 1994, 'National Parks and social involvement - An argument', Koedoe 37(1), 137-148.

Macleod, D.V.L., 2001, 'Parks or people: National Parks and the case of Del Este, Dominican Republic', Progress in Development Studies 1(3), 221-235.

Mahoney, K. \& Van Zyl, J., 2002., 'The impacts of tourism investment on rural communities: Three case studies in South Africa', Development Southern Africa 19(1), 83-103.

Maree, M., 2007, 'An investigation into the antecedents and origins of Tsitsikamma National Park', Honours mini dissertation, School of Business Management, North-West University.

Massyn, P.J., 2008, 'Citizen participation in the lodge sector of the Okavango Delta', in A. Spenceley, (ed.), Responsible tourism: Critical issues for conservation and development, p. 225-237, Earthscan, London.

Mbaiwa, J.E., 2003, 'The socio-economic and environmental impacts of tourism development on the Okavango Delta, North-western Botswana', Journal of Arid Environments 54(2), 447-446.

Mbaiwa, J.E., 2004, 'The socio-economic impacts and challenges of a community-based safari hunting tourism in the Okawango Delta, Botswana', Journal of Tourism Studies 15(2), 37-50.

Mbaiwa, J.E., 2005, 'Enclave tourism and its socio-economic impacts in the Okavango Delta, Botswana', Tourism Management 26, 157-172.

Myburgh, E. \& Saayman, M., 2002, Ecotourism in action: guidelines and principals, 2nd edn., Institute for Tourism and Leisure Studies, Potchefstroom

Pelser, A., 2003, 'Omgewingsbewaring in 'n nuwe era: 'n Nis vir die geestes- en sosiale wetenskappe' [Conservation in a new era: A niche for the human and social sciences]', Tydskrif vir Geesteswetenskappe 43(3/4), 164-176.

Relly, P., 2008, 'Madikwe Game Reserve, South Africa Investment and employment', in A. Spenceley, (ed.), Responsible tourism: Critical issues for conservation and development, pp. 267-282, Earthscan, London.

Saayman, M. \& Fouche, M., 2007, Executive summary of research profiles of selected National Parks in South Africa, Institute for Tourism and Leisure Studies, Potchefstroom.

Saayman, M. \& Saayman, A., 2006, 'Creating a framework to assess the economic contribution of National Parks in South Africa: The case study of the Addo Elephant National Park', Tourism Economics 12(4), 619-633.
Saayman, M., Saayman, A. \& Ferreira, M., 2009a, 'The socioeconomic impact of the Karoo National Park', Koedoe 51(1), $1-10$.

Saayman, M., Fouche, M. \& Kruger, M., 2009b, An analysis of visitors to selected National Parks in South Africa, Institute for Tourism and Leisure Studies, Potchefstroom.

Samuelsson, E. \& Stage, J., 2007 'The size and distribution of the economic impacts of Namibian hunting tourism', South African Journal of Wildlife Research 37(1), 41-52.

Shone, A. \& Parry, B., 2004, Successful event management, 2nd edn., Thomson, London.

Simpson, M.C., 2008, 'The impacts of tourism initiatives in rural livelihoods and poverty reduction in South Africa: Mathenjwa and Mqobela', in A. Spenceley (ed.), Responsible tourism: Critical issues for conservation and development, pp. 239-266 Earthscan, London.

Sims-Castley, R., Kerley, G.I.H., Geacg, B. \& Langholtz, J., 2005, 'Socio-economic significance of ecotourism-based private game reserves in South Africa's Eastern Cape Province', Parks 15(2), 6-17.

Spenceley, A. (ed.), 2008, Responsible tourism: Critical issues for conservation and development. Earthscan, London.

Streuders, C., 2008, 'Communication efficacy of South African National Parks: A case study of Karoo National Park', MCom thesis, School of Business Management, North-West University.

Suich, H., Busch, J. \& Barbancho, N., 2005, 'Economic impacts of transfrontier conservation areas: Baseline of tourism in the Kavango-Zambezi TFCA', Paper No. 4., Conservation International, Cape Town.

Telfer, D.J. \& Sharpley, R., 2008, Tourism and development in the developing world, Routledge, Abingdon.

Tiyce, M. \& Dimmock, K., 2000, 'Nimbin Mardi grass festival: The impacts', in J. Allen, R. Harris, L.K. Jago \& A.J. Veal, (eds.), Events beyond 2000: Setting the agenda. Proceedings of conference on event evaluation, research and education held in Sydney in July 2000, pp. 222-230, Australian Centre for Event Management, Sydney.

Turco, D.M., Swart, K., Bob, U. \& Moodley, V., 2003, 'Socioeconomic impacts of sport tourism in the Durban Unicity, South Africa', Journal of Sport Tourism 8(4), 223-239.

Tustin, D.H., Ligthelm, A.A., Martins, J.H. \& Van Wyk, H.J., 2005, Marketing research in practice, Unisa Press, Pretoria.

Van Der Merwe, L.H., 2008, 'The socio-economic impact of the Klein Karoo National Arts Festival', MCom thesis, School of Business Management, North-West University.

Van Der Merwe, P., Saayman, M. \& Rossouw, R., 2009, Socioeconomic impact of hunting in the Northern Cape Province, Institute for Tourism and Leisure Studies, Potchefstroom.

Vaughan, D.R., Farr, H. \& Slee, R.W., 2000, 'Estimating and interpreting the local economic benefits of visitor spending: An explanation', Leisure Studies 19(2), 95-118.

Williams, J. \& Lawson, R., 2001, 'Community issues and resident opinions of tourism', Annals of Tourism Research 28(2), 269-290. 